\title{
Silver nanoparticles modify VEGF signaling pathway and mucus hypersecretion in allergic airway inflammation
}

This article was published in the following Dove Press journal:

International Journal of Nanomedicine

13 March 2012

Number of times this article has been viewed

\author{
Sunhyae Jangl,* \\ ji Won Park ${ }^{2, *}$ \\ Hye Rim Cha' \\ Sun Young Jung' \\ Jeong Eun Lee' \\ Sung Soo Jung' \\ Ju Ock Kim' \\ Sun Young Kim' \\ Choong Sik Lee ${ }^{3}$ \\ Hee Sun Park' \\ 'Division of Pulmonology, Allergy and \\ Critical Care Medicine, Department \\ of Internal Medicine, Chungnam \\ National University Medical School, \\ Daejeon, ${ }^{2}$ Division of Pulmonology, \\ Department of Internal Medicine, \\ Daejeon St Mary's Hospital, College \\ of Medicine, The Catholic University \\ of Korea, Daejeon, ${ }^{3}$ Department \\ of Pathology, Chungnam National \\ University Medical School, Daejeon, \\ South Korea
}

*These authors contributed equally to this work
Correspondence: Hee Sun Park

Department of Internal Medicine, Chungnam National University Hospital and Cancer Research Institute,

Daesadong, Daejeon

$301-721$, South Korea

Tel +82 422808446

Fax +82 422575753

Email drpark@cnu.ac.kr

\begin{abstract}
The anti-inflammatory action of silver nanoparticles (NPs) has been reported in a murine model of asthma in a previous study. But more specific mechanisms of silver NPs in an attenuation of allergic airway inflammation have not yet been established. Vascular and mucous changes are believed to contribute largely in pathophysiology in asthma. Among various factors related to vascular changes, vascular endothelial growth factor (VEGF) plays a pivotal role in vascular changes in asthma. Mucin proteins MUC5AC and MUC5B have been implicated as markers of goblet cell metaplasia in lung pathologies. The aim of this study was to investigate the effects of silver NPs on VEGF signaling pathways and mucus hypersecretion. Ovalbumin (OVA)-inhaled female BALBc mice were used to evaluate the role of silver NPs and the related molecular mechanisms in allergic airway disease. In this study, with an OVA-induced murine model of allergic airway disease, it was found that the increased levels of hypoxia-inducible factor (HIF)-1 $\alpha$, VEGF, phosphatidylinositol-3 kinase (PI3K) and phosphorylated-Akt levels, and mucous glycoprotein expression (Muc5ac) in lung tissues were substantially decreased by the administration of silver NPs. In summary, silver NPs substantially suppressed mucus hypersecretion and PI3K/HIF-1 $\alpha$ /VEGF signaling pathway in an allergic airway inflammation.
\end{abstract}

Keywords: allergic airway disease, hypoxia inducible factor- $1 \alpha$, vascular endothelial growth factor

\section{Introduction}

Airway remodeling is a multifactorial process that involves complex interactions among cytokines, growth factors, and cell adhesion molecules, which can then influence epithelial cells and smooth-muscle cells of the airway as well as vascularization and mucus production. ${ }^{1}$ Allergic inflammation imposes several functional and structural changes on blood vessels in the respiratory tract; these include vasodilation, increased blood flow, angiogenesis, and increased vascular permeability of asthmatic airways. However, little is known about the functional significance of bronchial vascular remodeling in asthma. These changes may affect recruitment of inflammatory cells, hyperresponsiveness of airway, and regulation of airway caliber, as well as the level of disease control. Vascular endothelial growth factor (VEGF) plays a pivotal role in vascular remodeling and angiogenesis. Elevated VEGF levels have been observed in tissues and biological samples from individuals with asthma. ${ }^{2}$ Moreover, the VEGF level in asthmatic subjects correlates closely with disease activity, and correlates inversely with the dimension of airway caliber. Peribronchovascular angiogenesis is believed to contribute to airway narrowing 
and edema, which further augment airway obstruction in asthma. VEGF, also known as a vascular permeability factor, increases vascular permeability, allowing plasma proteins to leak into extravascular spaces. The plasma protein leakage induces a thickened, engorged, and edematous airway wall, resulting in narrowing of the airway lumen and profound alterations of the endothelial cell matrix. ${ }^{3}$ Overexpression of VEGF in airways of transgenic mice promotes angiogenesis as expected, but it also induces allergic inflammation, enhanced allergic sensitization, upregulation of subsequent $\mathrm{T}$ helper (Th)-2-type inflammatory responses, and mucous gland hyperplasia. ${ }^{4}$

Widespread airway mucus plugging has long been recognized as a central cause of death from asthma. ${ }^{5}$ This finding has been repeatedly confirmed, ${ }^{6}$ and a recent quantitative study of fatal asthma found that more than $98 \%$ of airways were occluded because of mucus. ${ }^{7}$ However, the effect of mucus hypersecretion on the symptoms, signs, and pathophysiology of less severe asthma subjects is still part of ongoing investigations. The effect of mucus hypersecretion on airflow obstruction in nonfatal asthma subjects has not yet been compared with the effects of other causes for airway closure such as extravasated plasma and airway narrowing from smooth-muscle contraction. ${ }^{8}$ Mucin protein MUC5B is the principal gel-forming mucin produced and secreted in small airways under healthy conditions, and MUC5AC is the principal gel-forming mucin upregulated during asthmatic inflammation.

Nanomaterials are a diverse class of extremely small $(<100 \mathrm{~nm})$ substances, formed by molecular engineering and designed to offer unique mechanical, optical, electrical, and magnetic properties. ${ }^{9}$ Recently, much effort has been devoted to the development of biomedical applications, such as drug delivery, for nanoparticles (NPs) because they are able to pass readily through cell membranes. ${ }^{10}$ Metal NPs have attracted attention owing to their important applications in a number of areas, such as catalysis and nanoscale electronics. ${ }^{11}$ Over the past couple of decades, noble metal NPs have been the subject of intense research for use in biomedicine. ${ }^{12,13}$ Some noble metal NPs are catalysts for reduction reactions; and thus, may be usable as antioxidants, to reduce reactive oxygen species (ROS) in the living body. ${ }^{14-16}$ Another candidate material for NPs is silver, which acts as a strong antimicrobial agent and disinfectant, possibly due to its ability to block respiratory enzyme pathways, alter microbial DNA, and modify cell walls. ${ }^{17}$ Silver NPs have been shown to block the proliferation and migration of endothelial cells. ${ }^{18}$
Some studies of silver NPs have demonstrated their cytoprotective activities toward human immunodeficiency virus-1-infected cells and their anti-inflammatory effects, through cytokine modulation upon topical application. ${ }^{19,20}$ The exact mechanisms of their anti-inflammatory effects are not fully understood. The authors of this present study previously reported the antioxidant and anti-inflammatory effects of silver NPs in an allergen-induced asthmatic animal model. ${ }^{21}$

In this present study, the authors hypothesize that silver NPs control the VEGF signaling pathway and mucin regulation in asthmatic airway inflammation.

\section{Materials and methods}

\section{Animals and experimental protocol}

Female BALBc mice, 8-10 weeks of age and free of murinespecific pathogens, were obtained from Damul Science Inc, (Daejeon, South Korea) and were maintained under standard laboratory conditions in a pathogen-free cage, with ad-libitum access to food and water. All animal experiments in this study were conducted in accordance with the guidelines of the Institutional Animal Care and Use Committee of the Chungnam National University Medical School.

Mice were sensitized on days 1 and 14 via an intraperitoneal injection of $20 \mu \mathrm{g}$ ovalbumin (OVA) (Sigma-Aldrich, St Louis, MO) emulsified in $1 \mathrm{mg}$ of aluminum hydroxide (Pierce Chemical Co, Rockford, IL) in a total volume of $100 \mu \mathrm{L}$. On days 21-23 after the initial sensitization, the mice were challenged for 30 minutes with an aerosol of $3 \%$ (weight/volume) OVA in saline (or saline alone as a control) using an ultrasonic nebulizer (NE-U12; Omron Co, Tokyo, Japan). Bronchoalveolar lavage (BAL) was performed 48 hours after the final challenge. At the time of lavage, the mice ( 8 per group) were sacrificed with an overdose of pentobarbital sodium $(100 \mathrm{mg} / \mathrm{kg}$ bodyweight, intraperitoneally). The chest cavity was exposed to allow for expansion, after which the trachea was carefully intubated and the catheter was secured with ligatures. Pre-warmed $0.9 \% \mathrm{NaCl}$ solution was slowly infused into the lungs and withdrawn. The aliquots were pooled and kept at $4^{\circ} \mathrm{C}$. A part of each pool was centrifuged, and the supernatant was kept at $-70^{\circ} \mathrm{C}$ until use. Total cell numbers were counted using a hemocytometer. Smears of BAL cells were prepared using a cytospin (Cellspin; Hanil Science Industrial Co, Ltd, Inchon, South Korea). To examine cell differentials, the smears were stained with Diff-Quik solution (Dade Diagnostics of PR Inc, Aguada, Puerto Rico). Two independent, blinded investigators counted the cells under a microscope. Approximately 400 cells were counted in each of four random locations. 
The inter-investigator variation was $<5 \%$, and the mean number of cells from both counts was used to estimate cell differentials.

\section{Cell culture}

The human umbilical vascular endothelial cells (HUVECs) were purchased from American Type Culture Collection (Rockville, MD). HUVECs were cultured in cell growth medium-2 (Lonza, Walkersville, MD) per manufacturer's recommendations on $2 \%$ gelatin-coated dishes. HUVECs were cultured between passages $2-8$ at $37^{\circ} \mathrm{C}$ in a humidified incubator with $5 \%$ (volume/volume) $\mathrm{CO}_{2}$. The cells were passaged when they approached $80 \%$ confluence with trypsin/ EDTA (Lonza) to provide maintenance cultures on $10 \mathrm{~cm}^{2}$ culture dishes. Cells were washed with phosphate-buffered saline and serum-starved in endothelial cell basal medium-2 (Lonza) for 48 hours prior to assays.

\section{Measurements of silver NPs}

Silver NPs were obtained from Nano Chemical Inc, (Silvergen $^{\mathrm{TM}}$, Daejeon, South Korea). For physicochemical studies (Table 1) of silver NPs, assistance was provided from the National Nanofab Center, Korea Advanced Institute of Science and Technology in Daejeon. Transmission electron microscopy (TEM) was performed by fixation on a Formvar carbon-coated copper grid (200 mesh) using an alcohol for prevention of aggregating particles and elimination of water. Primary particle size was measured using a transmission electron microscope (JEM-3020, 300 kV; JEOL, Tokyo, Japan). To enable the characterization of the samples using TEM imaging with a reasonable resolution, a solution of silver NPs was diluted in alcohol and was dispersed evenly for prevention of aggregating particles and elimination of water. Particles were spherical. The diameter measurements were performed at random. Mean surface area and number of particles were calculated based on mass concentration and average TEM diameter. In addition, the size and the size distribution (see Supplementary material) of the silver NPs were measured using a particle size analyzer (Nanotrac, Microtrac

Table I Physicochemical characteristics of silver nanoparticles

\begin{tabular}{ll}
\hline TEM diameter $(\mathrm{nm} \pm$ I SD) & $6.0 \pm 0.29$ \\
DLS size ( $\mathrm{nm} \pm$ PDI width) & $24.7 \pm 0.235$ \\
Crystalline structure & Amorphous \\
Zeta potential $(\mathrm{mV} \pm$ I SD) & $88.67 \pm 0.253$ \\
Mass concentration $(\mathrm{mg} / \mathrm{L})$ & 10,100 \\
Mean particle surface area $\left(\mathrm{nm}^{2} /\right.$ particle) & $0.11 \times 10^{3}$ \\
\hline
\end{tabular}

Abbreviations: DLS, dynamic light scattering; PDI, polydispersity index; SD, standard deviation;TEM, Transmission electron microscopy.
Inc, Largo, FL). NP size distribution was determined for the synthesized samples by diluting samples in deionized water to approximately $1 \mathrm{OD}$ and quantified using a zetasizer (Zetasizer NANO-ZS, Malvern Instruments Ltd, Malvern, UK). Hydrodynamic diameter was calculated based on the average of 10 runs of the intensity weighted Z-average performed at 25 using the cumulative fit function performed in triplicate.

\section{Administration of silver NPs or SU56 I4}

Silver NPs were dissolved in phosphate-buffered saline and administered by nebulizer (20 ppm, $40 \mathrm{mg} / \mathrm{kg}$ bodyweight/ day) five times to each animal at 24-hour intervals for 5 days prior to each challenge day (days 20-24), beginning 1 hour before the first challenge. VEGF receptor tyrosine kinase inhibitor SU5614 (Calbiochem-Novabiochem, San Diego, CA), diluted with dimethylsulfoxide $(2.5 \mathrm{mg} / \mathrm{kg})$ was administered intraperitoneally (three times, $100 \mu \mathrm{L}$ each), five times to each animal at 24-hour intervals for 5 days prior to each challenge day (days 20-24), beginning 1 hour after the first challenge.

For in-vitro studies, silver NPs were administered for 48 hours with different doses $(10,20,50,100,200$, or $500 \mu \mathrm{M})$.

\section{Determination of airway responsiveness}

Airway responsiveness was evaluated 24 hours after the final challenge, with the mice in an unrestrained conscious state. The mice were placed in a barometric plethysmographic chamber (All Medicus Co, Seoul, South Korea), and baseline readings were taken and averaged for 3 minutes. Increasing concentrations (from 2.5 to $25 \mathrm{mg} / \mathrm{mL}$ ) of aerosolized methacholine were nebulized through an inlet into the main chamber for 3 minutes. Readings were taken and averaged for 2 minutes after each nebulization. Enhanced pause (Penh) was used as a measure of airway responsiveness to methacholine. Penh is a dimensionless value that represents a function of the proportion of maximal expiratory to maximal inspiratory box pressure signals and a function of the timing of expiration. It was calculated according to the manufacturer's protocol as: Penh $=($ expiratory time/relaxation time -1$) \times$ (peak expiratory flow/peak inspiratory flow). The results are expressed as the increase in Penh following challenge with each concentration of methacholine, where the baseline Penh (after saline challenge) is defined as 1 .

\section{Western blot analysis}

Cells or lung tissues were homogenized in the presence of protease inhibitors, and protein concentrations were 
determined using the Bradford assay (Bio-Rad Laboratories Inc, Hercules, CA). Samples were loaded onto a gel and subjected to sodium dodecyl sulphate-polyacrylamide gel electrophoresis at $120 \mathrm{~V}$ for 90 minutes. The separated proteins were transferred to nitrocellulose membranes (GE Healthcare Bio-Sciences, Piscataway, NJ) via the wet transfer method (250 mA, 90 minutes). Nonspecific sites on the membranes were blocked by incubation for 1 hour in 5\% nonfat dry milk in Tris-buffered saline (TBS) containing Tween $^{\circledR} 20$ (TBS-T) $(25 \mathrm{mmol} / \mathrm{L}$ Tris, $\mathrm{pH} 7.5,150 \mathrm{mmol} / \mathrm{L}$ $\mathrm{NaCl}, 0.1 \%$ Tween 20 ), and the blots were then incubated overnight at $4{ }^{\circ} \mathrm{C}$ with an anti-interleukin (IL)-4 antibody (Serotec Ltd, Oxford, UK), anti-IL-5 antibody (Santa Cruz Biotechnology, Santa Cruz, CA), anti-IL-13 antibody (R\&D Systems, Inc, Minneapolis, MN), anti-hypoxia-inducible factor (HIF)-1 $\alpha$ antibody (Santa Cruz Biotechnology), antiHIF-1 $\beta$ antibody (Cell Signaling Technology Inc, Danvers, MA), anti-VEGF antibody (Santa Cruz Biotechnology), antiAkt1 antibody (Ser473, Epitomics Inc, Burlingame, CA), or anti-phosphorylated Akt1 (p-Akt) antibody (Epitomics Inc,), anti-phosphatidylinositol 3-kinase (PI3K) p85 antibody (Millipore, Bedford, MA), anti-epidermal growth factor receptor (EGFR) antibody (Cell Signaling Technology), and anti-Muc5ac antibody (Thermo Fisher Scientific Inc, Fremont, CA). Anti-rat or anti-mouse horseradish peroxidaseconjugated immunoglobulin $\mathrm{G}(\mathrm{IgG})$ was used to detect antibody binding. The membranes were stripped and re-probed with an anti-actin antibody (Sigma-Aldrich) to verify equal loading of proteins in each lane. Specific antibody binding was visualized by exposure of the membranes to photographic film, after treatment with enhanced chemiluminescence system reagents (GE Healthcare Bio-Sciences).

\section{Histological image analysis}

For histological analysis, the mice were sacrificed 48 hours after the final challenge, and the lungs and trachea were filled with fixative $(0.8 \%$ formalin, $4 \%$ acetic acid $)$. The trachea was ligated, and the lungs and trachea were dissected out. The lung tissues were fixed with 10\% (volume/volume) neutral-buffered formalin. Specimens were dehydrated and embedded in paraffin, and $4-\mu \mathrm{m}$-thick sections were cut using a Leica model 2165 rotary microtome (Leica Microsystems Nussloch GmbH, Nussloch, Germany). The sections were placed on slides, deparaffinized, and stained sequentially with hematoxylin 2 and eosin-Y (Richard-Allan Scientific, Kalamazoo, MI) or periodic acid-schiff (PAS) stain. All stained slides were evaluated via light microscopy under identical conditions with respect to magnification $(20 \times)$, gain, camera position, and background illumination. ${ }^{22}$ For immunohistochemistry analysis, the sections of specimens were dewaxed, rehydrated, then washed three times with phosphate-buffered saline ( $\mathrm{pH} 7.0$ ). Sections were placed in boiling citrate buffer, $\mathrm{pH}$ 6.0, for 25 minutes and then cooled with cold water for 3 minutes. These sections were rinsed in $1 \times$ TBS ( $\mathrm{pH} 7.6), 5$ minutes each and incubated with $\mathrm{H}_{2} \mathrm{O}_{2}$ for 10 minutes at room temperature, blocked in protein block (Dako A/S, Glostrup, Denmark) solution for 20 minutes, and followed by reaction with an affinity-purified rabbit polyclonal Muc5ac IgG (Thermo Fisher Scientific Inc, ) as a primary antibody overnight at $4{ }^{\circ} \mathrm{C}$ as 1:100 using Antibody Diluent (Dako A/S). After reaction with antibody, sections were washed twice in TBS-T ( $\mathrm{pH}$ 7.6) buffer for 5 minutes each. Sections were incubated sequentially with peroxidaseconjugated secondary antibodies and washed twice in TBS-T ( $\mathrm{pH}$ 7.6) buffer for 5 minutes each. Slides were visualized with Envision $^{\mathrm{TM}}$ Dual Link Advanced System (Dako A/S) and counterstained using a hematoxylin (Dako A/S). Slides were then dehydrated through an ascending ethanol series, cleared briefly in xylene, and mounted using Permount.

\section{Densitometric analysis and statistics}

All immunoreactive signals were scanned and densitometric analyses were performed using a Gel-Pro Analyzer (Media Cybernetics, Silver Spring, MD). Data are expressed as the mean \pm standard error of the mean. Statistical comparisons were made using one-way analysis of variance followed by Scheffe's test. Significant differences between two groups were determined using an unpaired Student's $t$-test. Statistical significance was set at $P<0.05$.

\section{Results}

\section{Effect of silver NPs on cellular changes in BAL fluids and lung inflammation of OVA-sensitized and OVA-challenged mice}

The numbers of total cells and eosinophils in BAL fluids were increased significantly at 48 hours after OVA inhalation, compared with the cell counts after saline inhalation (Figure 1). The administration of silver NPs or SU5614 blocked the increase in cell counts after OVA inhalation. Similarly, peribronchial and perivascular inflammation were increased significantly at 48 hours after OVA inhalation, compared with that after saline inhalation (Figure 1B and E). Peribronchial and perivascular inflammation after OVA 

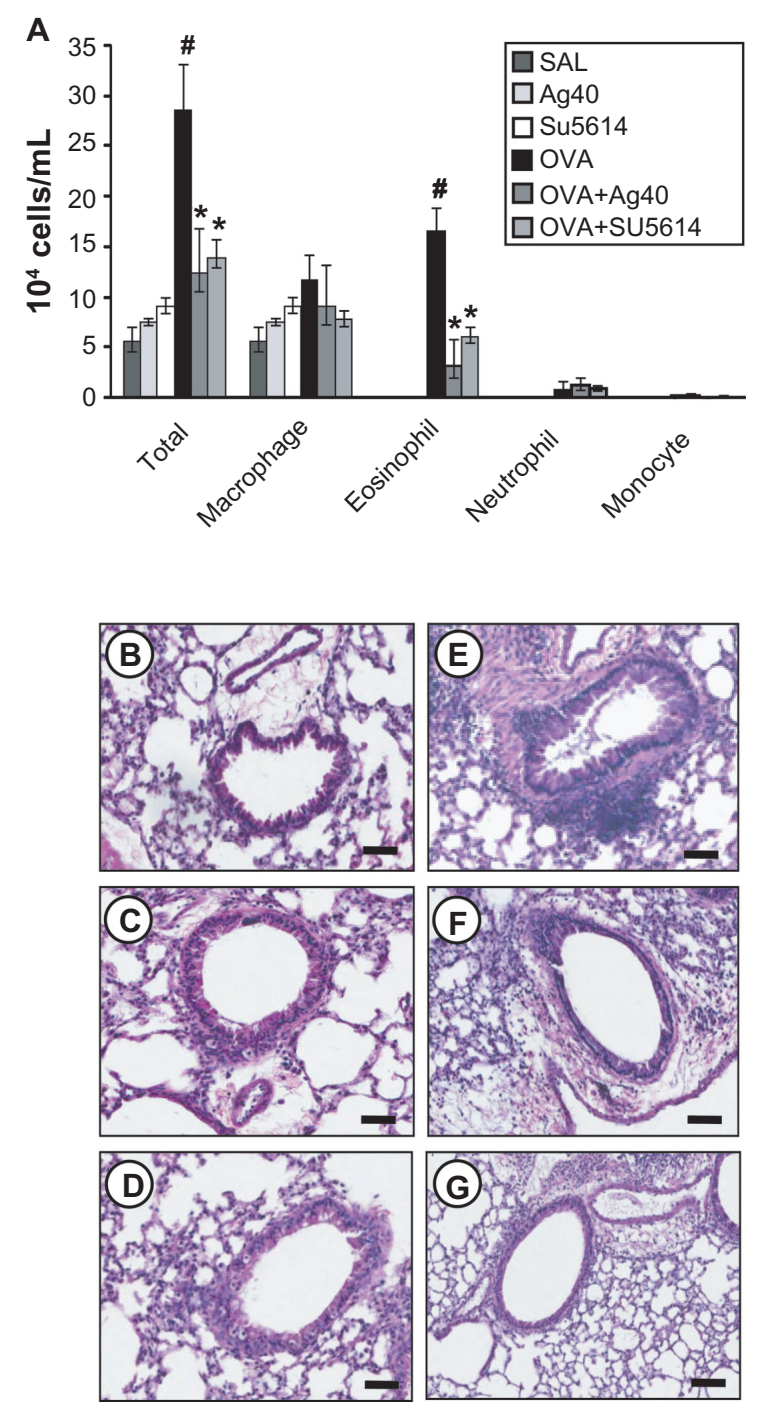

Figure I Effect of silver NPs on bronchial inflammation in ovalbumin-sensitized and ovalbumin-challenged mice. Sampling was performed 48 hours after the final challenge in saline-inhaled mice administered saline (SAL), saline-inhaled mice administered $40 \mathrm{mg} / \mathrm{kg}$ of silver NPs (Ag40) or SU56I4 (SU56I4), ovalbumin-inhaled mice administered saline (OVA), and ovalbumin-inhaled mice administered $40 \mathrm{mg} / \mathrm{kg}$ of silver NPs (OVA+Ag40) or SU56I4 (OVA+SU56/4). (A) The number of total and differential cellular components of BAL fluids. Bars indicate the mean \pm standard error of the mean for eight mice per group in four to six independent experiments. (B-G) Representative of H\&E-stained sections of the lungs.

Notes: $* P<0.05$ versus OVA; ${ }^{*} P<0.05$ versus SAL. Bars indicate scale of $50 \mu \mathrm{m}$. Abbreviations: BAL, bronchoalveolar lavage; H\&E, hematoxylin and eosin; NP, nanoparticle.

inhalation was significantly decreased with the administration of silver NPs or SU5614 (Figure 1F and G).

\section{Effect of silver NPs on IL-4, IL-5, and IL-I 3 expression in lung tissues of OVA- sensitized and OVA-challenged mice}

Western blot analysis revealed that IL-4, IL-5, and IL-13 levels were increased substantially in lung tissues at 48 hours
A

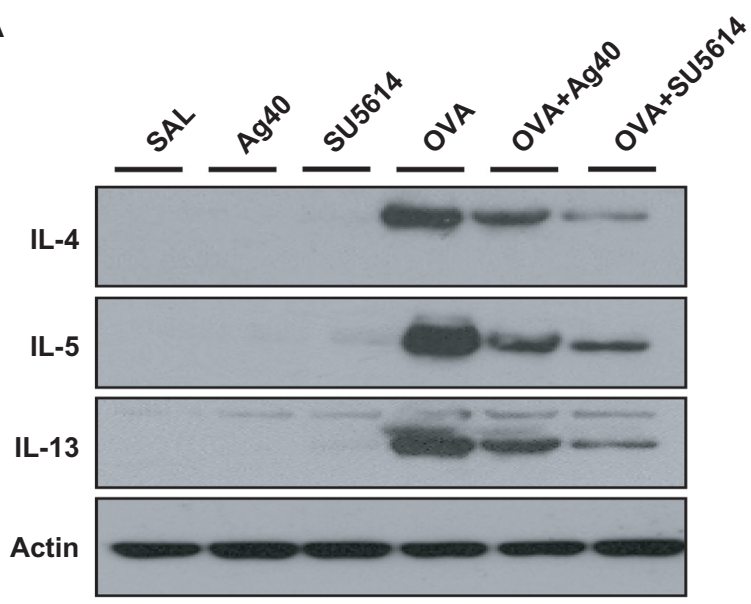

B

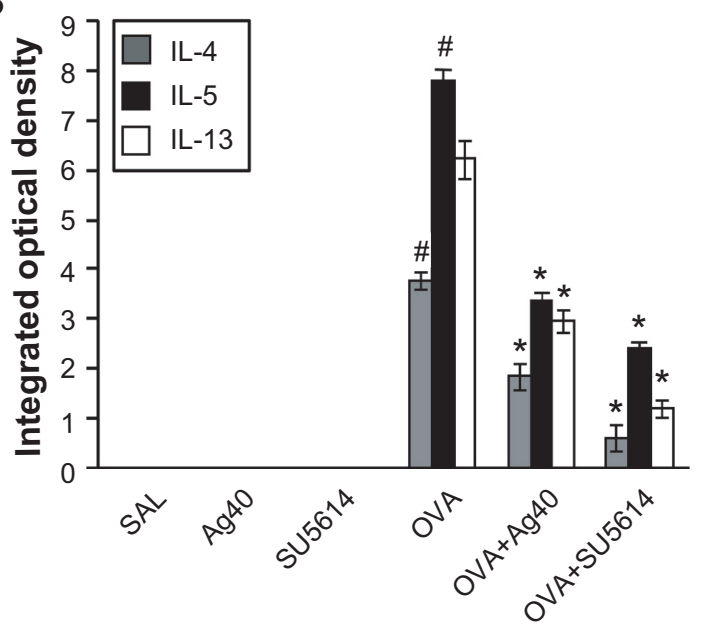

Figure 2 Effect of silver NPs on IL-4, IL-5, and IL-I3 expression in lung tissues collected from ovalbumin-sensitized and ovalbumin-challenged mice. Sampling was performed 48 hours after the final challenge in saline-inhaled mice administered saline (SAL), saline-inhaled mice administered $40 \mathrm{mg} / \mathrm{kg}$ of silver NPs (Ag40) or SU56/4 (SU56|4), ovalbumin-inhaled mice administered saline (OVA), and ovalbumin-inhaled mice administered $40 \mathrm{mg} / \mathrm{kg}$ of silver NPs (OVA+Ag40) or SU56I4 (OVA+SU56 I4). (A) Western blot analyses of IL-4, IL-5, and IL-13 in lung tissues. (B) Quantification of the IL-4, IL-5, and IL- 13 protein levels in (A) using Gel-Pro Analyzer. Bars indicate the mean \pm standard error of the mean and are representative of eight independent experiments using different preparations of lung tissues.

Notes: The relative protein content was calculated as the ratio of the integrated optical density of each protein to that of actin. $* P<0.05$ versus OVA; ${ }^{*} P<0.05$ versus SAL.

Abbreviations: IL, interleukin; NP, nanoparticle.

after OVA inhalation, compared with the levels after saline inhalation (Figure 2).

\section{Effect of silver NPs on upstream and downstream molecules of the VEGF signaling pathway}

By Western blot analysis, VEGF was shown to be constitutively overexpressed in OVA-sensitized and OVA-challenged 
A
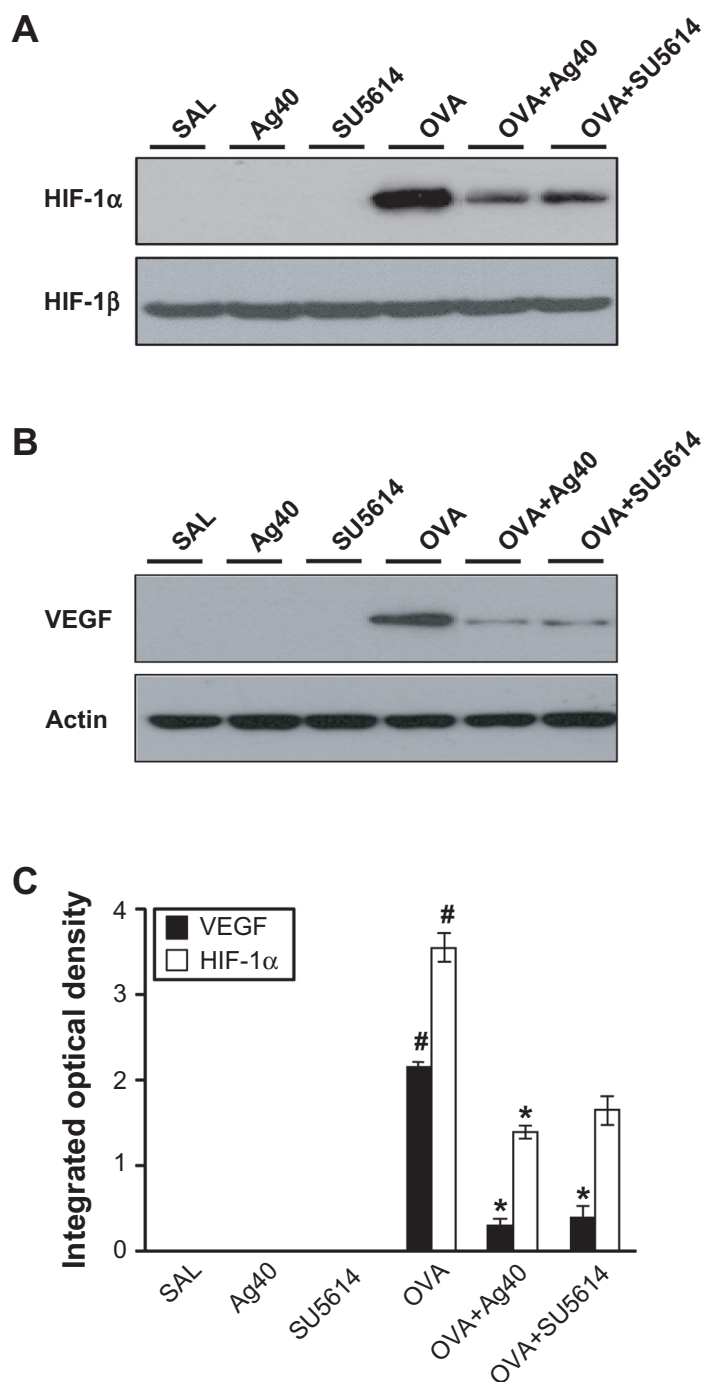

Figure 3 Effect of silver NPs on the protein expression of HIF-I $\alpha$ and VEGF in lung tissues collected from ovalbumin-sensitized and ovalbumin-challenged mice. HIF-I $\alpha$ or VEGF was measured 48 hours after the final challenge in saline-inhaled mice administered saline (SAL), saline-inhaled mice administered $40 \mathrm{mg} / \mathrm{kg}$ of silver NPs (Ag40) or SU56I4 (SU56I4), ovalbumin-inhaled mice administered saline (OVA), and ovalbumin-inhaled mice administered $40 \mathrm{mg} / \mathrm{kg}$ of silver NPs (OVA+Ag40) or SU56I 4 (OVA+SU56 I4). (A) Western blot analyses of HIF-I $\alpha$ and HIF-I $\beta$ from lung tissues. (B) Western blot analyses of VEGF from lung tissues. (C) HIF-I $\alpha$ and VEGF protein levels in A and B, respectively, were quantified using a Gel-Pro Analyzer and plotted as the integrated optical density, using Microsoft Excel. Densitometric analyses are presented as the relative ratio of each molecule to HIF-I $\beta$ or actin.

Notes: Bars indicate the mean \pm standard error of the mean and are representative of eight independent experiments using different preparations of total lung extracts. $* P<0.05$ versus OVA; ${ }^{*} P<0.05$ versus SAL.

Abbreviations: HIF, hypoxia-inducible factor; NP, nanoparticle; VEGF, vascular endothelial growth factor.

mice compared with the levels in control mice (Figure 3B and C). The levels of HIF-1 $\alpha$, which is a VEGF transcription regulator, $\mathrm{PI} 3 \mathrm{~K}$, and $\mathrm{p}$-Akt, were increased significantly after OVA inhalation (Figures 3A, C, and 4). The increases in VEGF and its upstream and downstream signal molecules after OVA inhalation were decreased substantially with the administration of silver NPs or SU5614.
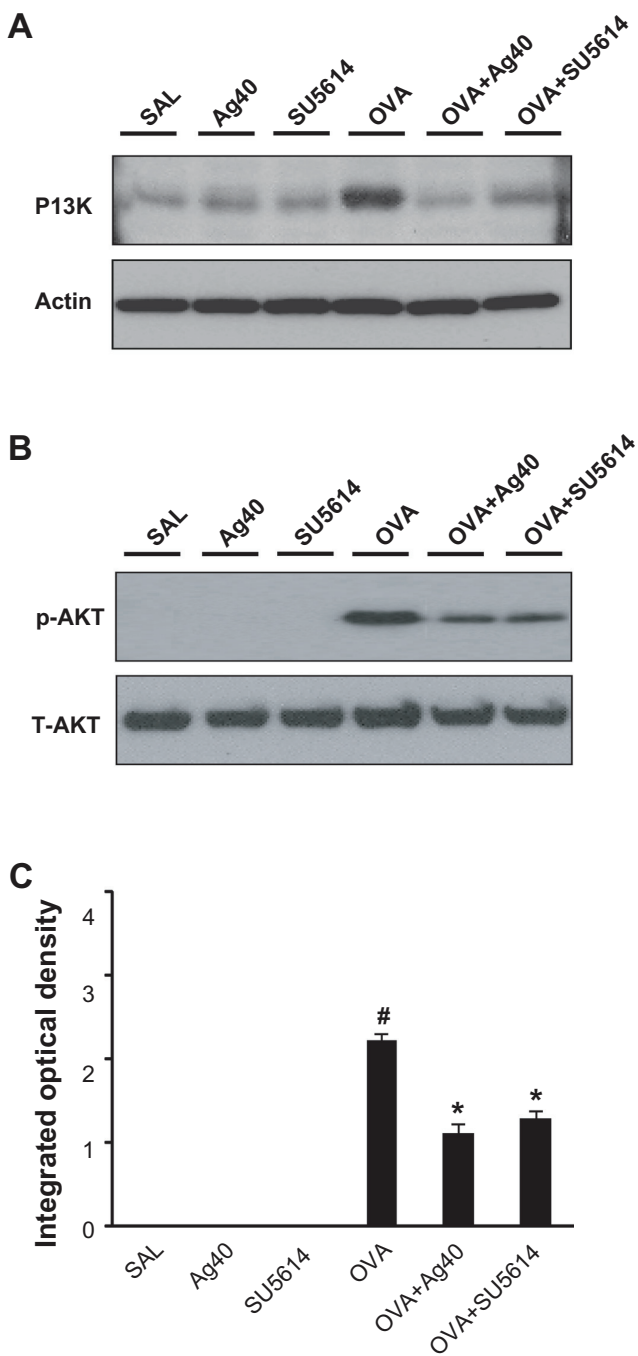

Figure 4 Effect of silver NPs on the protein expression of PI3K and Akt levels in lung tissues collected from ovalbumin-sensitized and ovalbumin-challenged mice. PI3K or Akt was measured 48 hours after the final challenge in saline-inhaled mice administered saline (SAL), saline-inhaled mice administered $40 \mathrm{mg} / \mathrm{kg}$ of silver NPs (Ag40) or SU56/4 (SU56/4), ovalbumin-inhaled mice administered saline (OVA), and ovalbumin-inhaled mice administered $40 \mathrm{mg} / \mathrm{kg}$ of silver NPs (OVA+Ag40) or SU56I4 (OVA+SU56I4). (A) Western blot analyses of PI3K from lung tissues. (B) Western blot analyses of phosphorylated-Akt protein levels from lung tissues. (C) phosphorylated-Akt levels were quantified using a Gel-Pro Analyzer and plotted as the integrated optical density, using Microsoft Excel. Densitometric analyses are presented as the relative ratio of each molecule to total Akt.

Notes: Bars indicate the mean \pm standard error of the mean and are representative of eight independent experiments using different preparations of total lung extracts. $* P<0.05$ versus OVA; ${ }^{*} P<0.05$ versus SAL.

Abbreviations: NP, nanoparticle; $\mathrm{p}-\mathrm{AKT}$, phosphorylated-Akt; PI3K, phosphatidylinositol-3 kinase; T-AKT, total Akt.

\section{Dose-dependent effect of silver NPs on the protein expression of VEGF and its upstream and downstream molecules in HUVECs}

To determine whether the silver NPs are closely involved and have a dose-dependent effect in the VEGF signaling pathway, Western blot analyses of the expressions of HIF-1 $\alpha$, 
VEGF, and PI3K in HUVECs were performed. The levels of HIF-1 $\alpha$, VEGF, and PI3K were identified at 48 hours in HUVECs. Elevated HIF-1 $\alpha$, VEGF, and PI3K levels in HUVECs were found to be significantly decreased dosedependently (Figure 5). The levels of HIF-1 $\alpha$, VEGF, and PI3K levels are significantly decreased at the dose of 100 , 200 , and $500 \mu \mathrm{m}$ silver NPs. Similarly, the elevated levels of those proteins were substantially reduced by the administration of SU5614.

\section{Effect of silver NPs on mucus hypersecretion in lung tissues from OVA-sensitized and OVA-challenged mice}

To investigate the effect of silver NPs on mucus hypersecretion, a PAS stain was performed. Substantial mucus production was induced in OVA-sensitized and OVA-challenged mice with increased PAS-stained mucins in epithelial goblet cells. This increase was reduced substantially by the administration of silver NPs or SU5614 (Figure 6). Also investigated was whether silver NPs could reduce protein levels of Muc5ac in mice. Western blot analysis showed significantly increased levels of Muc5ac in total protein extracts from lung tissues of mice at 48 hours after OVA inhalation, compared with the levels in control mice. This increase in Muc5ac after OVA inhalation was significantly decreased with the administration of silver NPs or SU5614 (Figure 7).

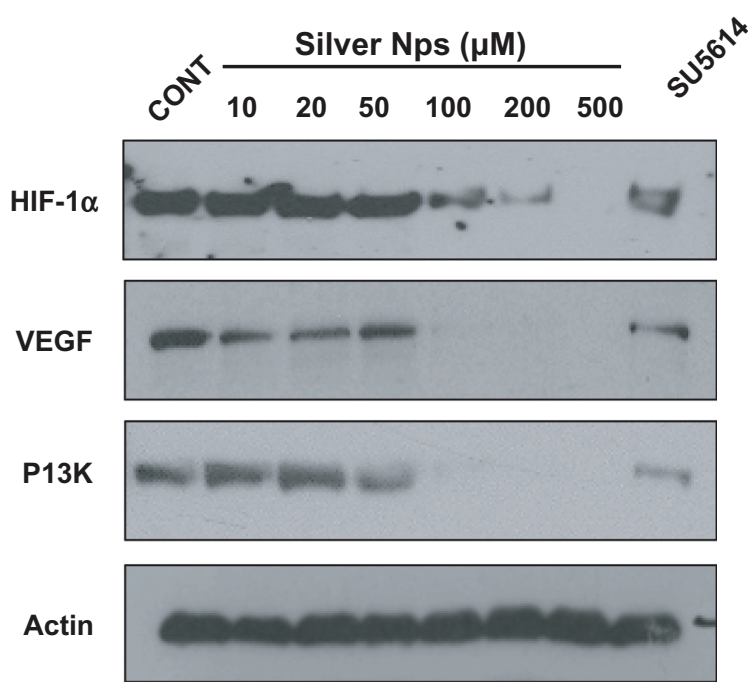

Figure 5 Dose-dependent effect of silver NPs and effect of SU56I4 on PI3K, HIF-I $\alpha$, and VEGF levels in HUVECs. Expression of PI3K, HIF-I $\alpha$, or VEGF protein was examined by immunoblot analysis. Starved cells were treated with 10, 20, 50, 100,200 , or $500 \mu \mathrm{M}$ silver NPs or SU56I4 for 48 hours. Blots were stripped and reprobed for actin as a loading contol.

Abbreviations: CONT, control; HIF, hypoxia-inducible factor; NP, nanoparticle; PI3K, phosphatidylinositol-3 kinase; VEGF, vascular endothelial growth factor.
Immunohistochemical staining showed the localization of immunoreactive Muc5ac in goblet cells of the bronchial epithelial cell layers of OVA-sensitized and OVA-challenged mice. The immunostaining of Muc5ac in goblet cells after OVA inhalation was decreased substantially after the administration of silver NPs or SU5614 (Figure 6).

\section{Effect of silver NPs on EGFR expression in lung tissues of OVA-sensitized and OVA-challenged mice}

By Western blot analysis, EGFR was shown to be constitutively overexpressed in OVA-sensitized and OVA-challenged mice compared with the levels in control mice (Figure 8). This increase in EGFR expression after OVA inhalation was substantially decreased with the administration of silver NPs or SU5614.

\section{Effect of silver NPs on airway hyperresponsiveness}

Airway responsiveness was assessed based on an increase in Penh in response to increasing doses of methacholine. In OVA-sensitized and OVA-challenged mice, the Penh

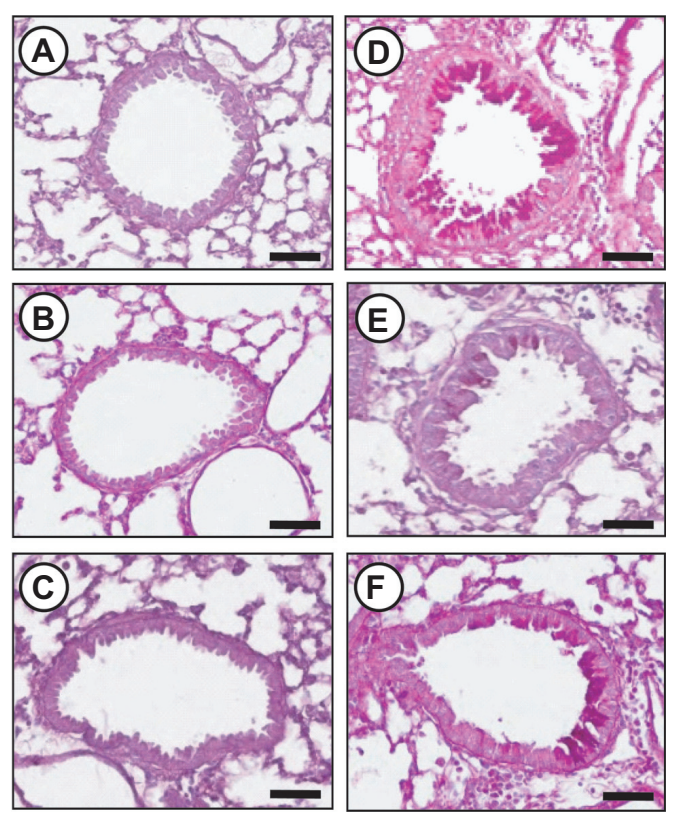

Figure 6 Effect of silver NPs and SU56/4 on mucus production in OVA-sensitized and OVA-challenged mice. Histological examination was obtained from lung tissue 48 hours after the final challenge in saline-inhaled mice administered saline $(\mathbf{A})$, salineinhaled mice administered $40 \mathrm{mg} / \mathrm{kg}$ of silver NPs (B), or SU56I4 (C), OVA-inhaled mice administered saline (D), OVA-inhaled mice administered $40 \mathrm{mg} / \mathrm{kg}$ of silver NPs (E), or SU56I4 (F). Paraffin section slide of lung tissues were stained periodic acid-schiff stain. Notes: All stained slides were evaluated via light microscopy under identical conditions with respect to magnification (20x), gain, camera position, and background illumination. Bars indicate $50 \mu \mathrm{m}$.

Abbreviations: NP, nanoparticle; OVA, ovalbumin. 

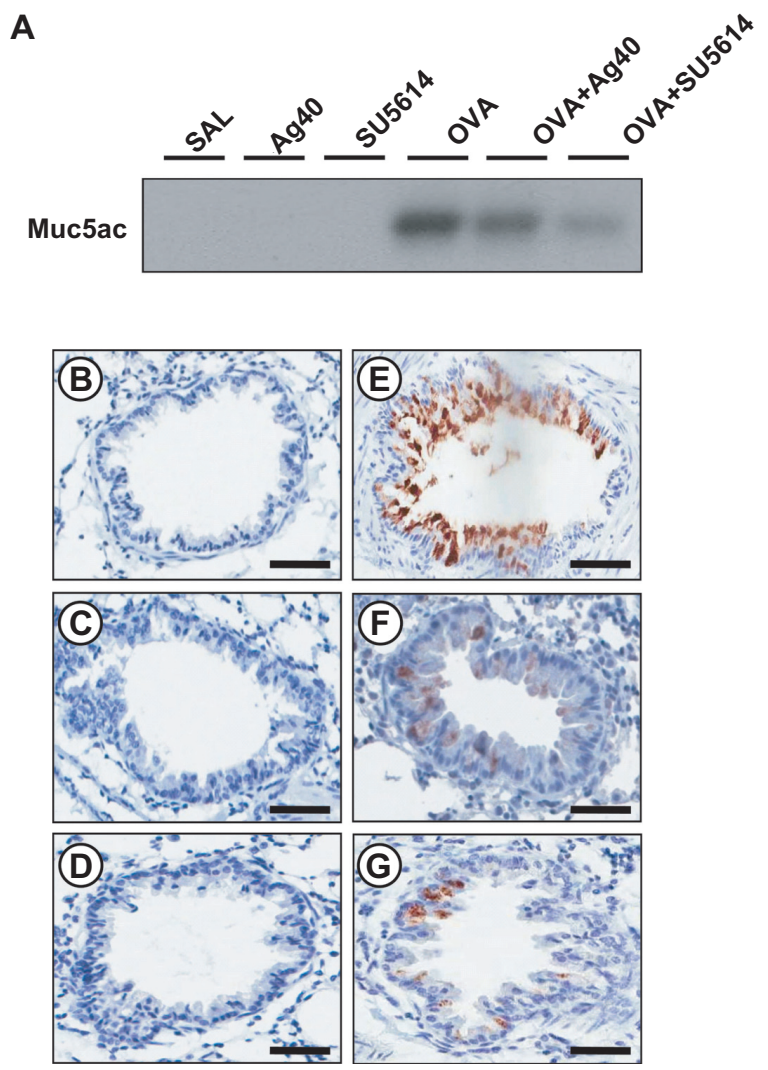

Figure 7 Effect of silver NPs and SU56/4 on the protein expression of Muc5ac in lung tissues collected from ovalbumin-sensitized and ovalbumin-challenged mice. (A) Western blot analyses of Muc5ac in total protein extracts from lung tissues. (B-G) Localization of immunoreactive Muc5ac in the bronchiolar epithelial layer. Muc5ac was measured 48 hours after the final challenge in saline-inhaled mice administered saline (SAL or B), saline-inhaled mice administered silver NPs (Ag40 or C), saline-inhaled mice administered SU56I4 (SU56I4 or D), ovalbumin-inhaled mice administered saline (OVA or E), ovalbumin-inhaled mice administered silver NPs (OVA+Ag40 or F), and ovalbumin-inhaled mice administered SU56/4 (OVA+SU56I 4 or $\mathbf{G})$.

Notes: Brown color indicates Muc5ac-positive cells. Bars indicate $50 \mu \mathrm{m}$. Abbreviation: NP, nanoparticle.

dose-response curve was shifted to the left compared with the control curve (Figure 9). In addition, Penh produced by the administration of methacholine at $25 \mathrm{mg} / \mathrm{mL}$ was significantly greater in OVA-inhaled mice than in control mice. OVA-sensitized and OVA-challenged mice treated with silver NPs or SU5614 showed a substantial reduction in methacholine $(25 \mathrm{mg} / \mathrm{mL})$ - induced Penh compared with untreated mice after OVA inhalation. These results indicate that silver NP or SU5614 treatment reduces OVA-induced airway hyperresponsiveness.

\section{Discussion}

The authors of this present study have previously demonstrated that silver NPs have negative effects in pulmonary Th-2 inflammation and airway hyperresponsiveness and in nuclear factor (NF)- $\mathrm{\kappa B}$ nuclear translocation and attenuation

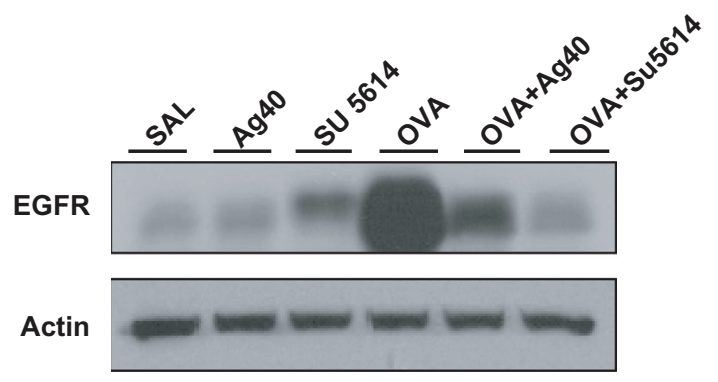

Figure 8 Effect of silver NPs and SU5614 on the protein expression of EGFR in lung tissues collected from ovalbumin-sensitized and ovalbumin-challenged mice. Western blot analysis of EGFR in total protein extracts from lung tissues. EGFR was measured 48 hours after the final challenge in saline-inhaled mice administered saline (SAL), saline-inhaled mice administered $40 \mathrm{mg} / \mathrm{kg}$ of silver NPs (Ag40) or SU56I4 (SU56|4), ovalbumin-inhaled mice administered saline (OVA), and ovalbumin-inhaled mice administered $40 \mathrm{mg} / \mathrm{kg}$ of silver NPs (OVA+Ag40) or SU56I4 (OVA+SU56I4). Blots were stripped and reprobed for actin as a loading contol.

Abbreviations: EGFR, epidermal growth factor receptor; NP, nanoparticle.

of ROS generation as an underlying mechanism. ${ }^{21}$ In addition, they previously provided safety profiles for inhaled silver NPs. In the present study, the mechanism(s) that contribute to the anti-asthmatic role of silver NPs by evaluating their effects on VEGF activity and Muc5ac overexpression in allergen-induced airway inflammation was further investigated.

VEGF is an endothelial cell-specific mitogenic peptide with key roles in vasculogenesis and angiogenesis. ${ }^{3}$ It also increases vascular permeability, allowing plasma proteins to leak into extravascular spaces, which leads to edema and profound alterations in the extracellular matrix. VEGF is a major determinant of pulmonary inflammation and vascular airway remodeling in asthma., ${ }^{2,4}$ Thus, inhibition of VEGF

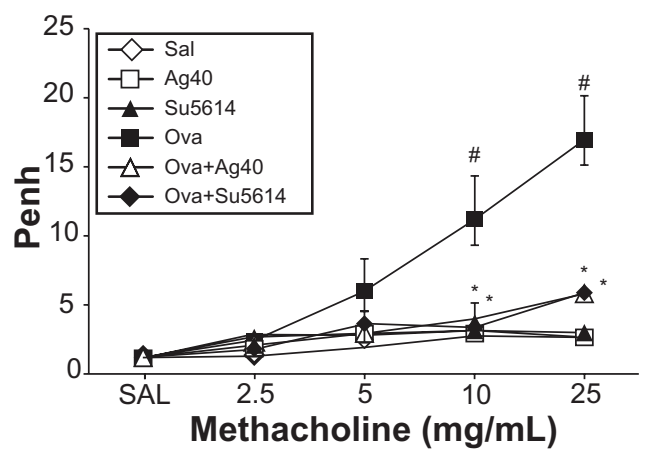

Figure 9 Effect of silver NPs on airway responsiveness to inhaled methacholine in ovalbumin-sensitized and ovalbumin-challenged mice. Airway hyperresponsiveness was measured at 24 hours after the final challenge in saline-inhaled mice administered saline (SAL), saline-inhaled mice administered $40 \mathrm{mg} / \mathrm{kg}$ of silver NPs (Ag40) or SU56 I 4 (SU56|4), ovalbumin-inhaled mice administered saline (OVA), and ovalbumin-inhaled mice administered $40 \mathrm{mg} / \mathrm{kg}$ of silver NPs (OVA+Ag40) or SU56I4 (OVA+SU56I4). Notes: Penh values were obtained in response to increasing doses (from 2.5 to $25 \mathrm{mg} / \mathrm{mL}$ ) of methacholine. Bars indicate the mean \pm standard error of the mean for eight mice per group in four to six independent experiments. ${ }^{*} P<0.05$ versus OVA; $" P<0.05$ versus SAL.

Abbreviations: NP, nanoparticle; Penh, enhanced pause. 
activity presents a potential therapeutic strategy. Similar to the effects of SU5614, which is a potent inhibitor of VEGF receptor tyrosine kinase, silver NPs consistently decreased in the levels of VEGF protein and its upstream and downstream signal molecules HIF- $1 \alpha$ and PI3K respectively, in the present study. Previous studies have demonstrated that VEGF receptor inhibitors induce VEGF activity in a murine model of asthma ${ }^{23,24}$ and in cancer cell lines under normoxic conditions. ${ }^{25}$ From many studies, sorafenib was developed as a receptor tyrosine kinase inhibitor and was approved by the United States Food and Drug Administration in 2005. It has been studied as a multi-kinase inhibitor that targets not only VEGF receptor tyrosine kinase but also other kinases such as Raf serine/threonine kinase. ${ }^{26,27}$ These findings indicate that the inhibition of VEGF receptor may affect a variety of signaling kinases.

HIF is a heterodimer composed of one of three subunits (HIF-1 $\alpha$, HIF- $2 \alpha$, or HIF-3 $\alpha$ ) and a constitutively expressed HIF-1 $\beta$ subunit (also known as the aryl hydrocarbon receptor nuclear translocator subunit). ${ }^{28}$ As an oxygen-dependent transcriptional activator, HIF plays crucial roles in tumorrelated angiogenesis, inflammatory processes, and mammalian development. HIF-1 $\alpha$ regulates VEGF transcription by binding to the VEGF promoter. ${ }^{28}$ Despite the central importance of hydroxylases in sensing oxygen tension and regulating HIF-1 activity, HIF-1 is also regulated in an oxygen-independent manner. Various signaling pathways are involved in the expression of HIF- $1 \alpha .^{29}$ Growth factors, cytokines (tumor necrosis factor $\alpha$ and IL-1 $\beta$ ), bacterial products, environmental stimuli, ROS, and other signaling molecules have been implicated in the control of HIF-1 under nonhypoxic conditions. ${ }^{28,30-35}$ Recently, it was reported that VEGF expresses and stabilizes HIF- $1 \alpha$ via its specific receptor. ${ }^{36}$ The authors of this present study have previously shown that the increased VEGF expression in OVA-exposed mice is decreased by the inhibition of HIF-1 $\alpha$ activation. ${ }^{34}$

VEGF-mediated signaling can occur through the PI3K/ Akt pathway. ${ }^{37}$ In the present study, Western blotting with an antibody to the regulatory subunit of PI3K (p85) showed that $\mathrm{PI} 3 \mathrm{~K}$ protein levels in lung tissues of mice were increased after OVA inhalation and that the increase was decreased by the administration of silver NPs. The current view is that PI3K is present as a preformed, inactive $\mathrm{p} 85-\mathrm{p} 110$ complex in the cytoplasm of resting cells, poised for activation in response to appropriate cues. Treatment with silver NPs was also associated with the inhibition of Akt phosphorylation, consistent with the downregulation of PI3K signaling. However, PI3K activity directly measuring phosphatidylinositol 3,4,5-triphosphate was not observed. Exactly how silver NPs activate the PI3K/Akt pathway is unclear at this time, but data obtained in this present study suggest that silver NPs may post-translationally enhance PI3K expression and Akt phosphorylation. These observations imply that activation of the PI3K/Akt pathway is involved in the anti-VEGF activity of silver NPs.

The phosphorylation of some proteins can stimulate HIF- $1 \alpha$ transactivation or synthesis by activating the mitogen-activated protein kinase (MAPK) or PI3K pathway. ${ }^{29}$ In the present study, the effect of silver NPs on signaling upstream of HIF-1 $\alpha$, starting with the phosphorylation of EGFR, was examined. EGFR expression is upregulated in the airway epithelium of humans with asthma, cystic fibrosis, and chronic obstructive pulmonary disease. ${ }^{38}$ EGFR signaling is prominent during cellular stress, and EGFR induces HIF-1 $\alpha$ mRNA synthesis. Downstream effectors of EGFR activation include p38 MAPK and extracellular signal-regulated kinase (ERK), which increase HIF pathway activation under normoxic conditions by inducing HIF- $1 \alpha$ mRNA synthesis. ${ }^{39-42}$ Thus, post-EGFR signaling via at least one of the signaling cascades, PI3K, ERK, or p38, activates HIF mRNA production. In the present study, the expression of EGFR was upregulated in the lung tissues of mice, as has been well established in many previous asthma-related studies. ${ }^{43-45}$ Thus, silver NPs regulate EGFR and may affect post-EGFR signaling molecules such as PI3K as well as HIF- $1 \alpha$ levels in an allergic airway model, suggesting a possible mechanism of silver NPs in the regulation of allergic airways. Further studies are needed to confirm these findings. PI3K/Akt signaling participates in multiple cellular metabolic pathways, particularly in cellular energy metabolism ${ }^{46}$ Akt is the key signaling molecule in cell survival, proliferation, growth, and differentiation, and is involved in angiogenesis through the pro-survival function of VEGF. ${ }^{47}$ Moreover, Akt phosphorylation is an important event in regulating the survival of growth factors such as VEGF, transcription factors such as HIF-1 $\alpha$, and oncogenes. ${ }^{48}$ Small molecules that inhibit the VEGF tyrosine kinase receptor have been shown to have dual efficacy in blocking HIF-1 and the VEGF receptor pathway. The present study demonstrated that VEGF signaling affects HIF-1 $\alpha$ levels in an allergic airway animal model, leading to the hypothesis that HIF-1 $\alpha$ expression would be affected by blocking the VEGF signaling pathway and EGFR phosphorylation. To provide more specific data that silver NPs or SU5614 are involved in the PI-3K-HIF-1 $\alpha$-VEGF pathway, an in-vitro study was performed using HUVECs. HUVECs are activated by a variety of cytokines and growth factors 
and secret various cytokines, adhesion molecules, and growth factors including VEGF. Western blot analyses of the expression of VEGF, HIF-1 $\alpha$, and PI3K (p85) were performed. Silver NPs or SU5614 significantly reduced the expression of HIF-1 $\alpha$, VEGF, and PI3K in HUVECs. The basal expression of these molecules was dose-dependently affected by silver NPs. Although there may be various pathways to modify VEGF-VEGF receptor signaling, the findings of this study indicate that silver NPs, at least in part, can affect VEGF signaling pathway in a dose-dependent manner as seen with the VEGF receptor tyrosine kinase inhibitor. Consistently, the data showed that increased PI3K levels, Akt phosphorylation, and HIF-1 $\alpha$ expression in OVA-challenged mice were inhibited by the VEGF receptor tyrosine kinase inhibitor SU5614 and by silver NPs. These observations imply that the VEGF receptor is involved in PI3K/Akt activation and in HIF- $1 \alpha$ expression in vitro and in vivo. Lee et al recently demonstrated a PI3 K-HIF-1 $\alpha$-VEGF signaling loop in an OVA-challenged murine model of asthma. ${ }^{49}$ This signaling cascade is important for both mechanistic understanding and therapeutic intervention, as VEGF is a potent stimulator of airway inflammation and airway remodeling in asthma. ${ }^{2,4,23}$ Taken together, these data support the role of silver NPs in the PI3 K-HIF-1 $\alpha$-VEGF signaling loop.

In the present study, increased expression of the Muc5ac in lung tissues from OVA-challenged mice was also shown. Under pathological conditions including asthma, airway mucins may be produced and secreted in greatly increased quantities (mucus hypersecretion). This can be observed pathologically as an increase in intracellular mucins (mucous metaplasia) or as an increase in mucus in the airway lumen. Excessive luminal mucus can become impacted and lead to airway closure. The principal cells in the airway that regulate mucus clearance and secretion include ciliated epithelial cells, goblet cells, and Clara cells in the airway surface epithelium, and serous cells and mucous cells in the submucosal glands. Young et al demonstrated that mRNA expression of Muc5ac, the most highly induced gel-forming mucin in the airways of antigen-challenged mice, increases over the same time course as airway inflammation and goblet cell metaplasia after antigen challenge in transgenic mouse model. ${ }^{50}$

Several orthologous human and mouse genes encode gel-forming mucins. Four of these (MUC2, MUC5AC, MUC5B, and MUC6) are present in tandem as a conserved cluster on human chromosome $11 \mathrm{p} 15$ and on the syntenic mouse chromosome $7 \mathrm{~F} 5 .{ }^{51} \mathrm{MUC} 19$ is present on chromosome $12 \mathrm{q} 12$ in humans and $15 \mathrm{E} 3$ in mice. ${ }^{52,53}$ MUC5AC and MUC5B have been implicated as markers of goblet cell metaplasia in lung pathologies based on expression studies in humans, animal models, and cell culture. ${ }^{54,55}$ The predominant species in the lung are MUC5AC and MUC5B, which in larger mammals are thought to be secreted from goblet cells in the superficial epithelium and from submucosal glands, respectively. ${ }^{56}$ Previous studies of human MUC5AC have shown direct relationships between proand anti-inflammatory mediators acting upon cis elements within the MUC5AC promoter. Two of these studies used in-vitro reporter assays to identify potential roles for NF- $\mathrm{\kappa B}$ and glucocorticoid-response elements (GREs) in activation and repression of the MUC5AC promoter. ${ }^{50,57}$ However, it was demonstrated that NF- $\kappa \mathrm{B}$ expression is not necessary for the induction of MUC5AC expression and goblet cell metaplasia, and the alignment of the $5^{\prime}$ flanking regions of MUC5AC orthologs does not reveal any well conserved NF- $\kappa \mathrm{B}$ sites or GREs. ${ }^{57}$ According to previous reports, $\mathrm{NF}-\kappa \mathrm{B}$ is not directly involved in mediating cytokines, especially IL-13, or in activating MUC5AC, although NF- $\kappa \mathrm{B}$ involved in Th-2 cytokine expression and, as such, may play an indirect role in mucin production. Control of the MUC5AC promoter derives from activation of cellular stress (HIF-1), damage ( $\beta$-catenin/Lef1), and remodeling/ repair (TGF- $\beta / \mathrm{SMAD})$ pathways. ${ }^{50}$

In addition, the elements within the first $\mathrm{kb}$ of the $5^{\prime}$ flanking region of MUC5AC promoter respond to stimulation by cytokines such as IL-13 and EGF. ${ }^{58}$ Many cytokines such as IL-5, IL-9, and IL-17 induce mucus metaplasia and mucin gene expression, but IL-13 and IL-4R $\alpha$ appear to be critical, in vivo and in vitro. ${ }^{59}$ In the present study, increased levels of HIF- $1 \alpha$ and Th- 2 cytokines IL-4, IL-5, and IL-13 were attenuated by the administration of silver NPs, suggesting that silver NPs may regulate mucous hypersecretion at least in part, via blocking HIF-1 $\alpha$ and Th-2 cytokines. Furthermore, the activation of EGFR, which was shown to be upregulated in the lung tissues in the present and previous studies, ${ }^{43-45}$ is critical for the induction of Muc5ac and mucous metaplasia in animal models and the induction of MUC5AC in epithelial cells of human airway in response to allergens, viruses, neutrophils, and cigarette smoke. ${ }^{60-65}$

The closure of hyperresponsive airway due to mucus hypersecretion has not been compared with airway closure and narrowing from other causes. However, the pharmacological inhibition of mucin secretion blocked increase of methacholine-induced airway resistance by approximately $80 \%$ in a mouse model of allergic asthma, ${ }^{66}$ suggesting a major contribution of mucus hypersecretion under some circumstances. 
In summary, silver NPs decreased VEGF signaling and Muc5ac protein expression. Taken together, the present results indicate that silver NPs have the potential to therapeutically suppress Muc5ac expression, EGFR levels, and PI3K/HIF-1 $\alpha /$ VEGF signaling pathways in airways with minimal toxicity. The multifunctional or multidirectional action of silver NPs may be helpful in the treatment of allergic asthma.

\section{Acknowledgments}

The authors give special thanks to Professor Jaseok P Koo (Yale University) for insightful recommendations and advice. This study was financially supported by research fund of Chungnam National University in 2007 and Chungnam National University Hospital Research Fund, 2010 .

\section{Disclosure}

The authors report no conflicts of interest in this work.

\section{References}

1. Holgate ST, Lemanske RF Jr, O’Byrne PM, Kakumanu S, Busse WW. Asthma pathogenesis. In: Adkinson NF Jr, Bochner BS, Busse WW, Holgate ST, Lemanske RF Jr, Simons FE, editors. Middleton's Allergy Principles and Practice. 7th ed. Philadelphia, PA: Mosby Elsevier Inc. 2009;2:911.

2. Lee YC, Lee HK. Vascular endothelial growth factor in patients with acute asthma. J Allergy Clin Immunol. 2001;107:1106-1108.

3. McCullagh A, Rosenthal M, Wanner A, et al. The bronchial circulation-worth a closer look: a review of the relationship between the bronchial vasculature and airway inflammation. Pediatr Pulmonol. 2010;45:1-13.

4. Lee CG, Link H, Baluk P, et al. Vascular endothelial growth factor (VEGF) induces remodeling and enhances TH2-mediated sensitization and inflammation in the lung. Nat Med. 2004;10:1095-1103.

5. Voynow JA, Rubin BK. Mucins, mucus, and sputum. Chest. 2009; 135:505-512.

6. Williams OW, Sharafkhaneh A, Kim V, Dickey BF, Evans CM. Airway mucus: from production to secretion. Am J Respir Cell Mol Biol. 2006;34:527-536.

7. Kuyper LM, Paré PD, Hogg JC, et al. Characterization of airway plugging in fatal asthma. Am J Med. 2003;115:6-11.

8. Lundblad LK, Thompson-Figueroa J, Allen GB, et al. Airway hyperresponsiveness in allergically inflamed mice: the role of airway closure. Am J Respir Crit Care Med. 2007;175:768-774.

9. Tsuji JS, Maynard AD, Howard PC, et al. Research strategies for safety evaluation of nanomaterials, part IV: risk assessment of nanoparticles. Toxicol Sci. 2006;89:42-50.

10. Heger M. Safety of new bacteria-killing coating questioned. April 20, 2008. Available from: http://www.livescience.com/technology/080421silver-nano.html. Accessed January 4, 2012

11. El-Sayed MA. Small is different: shape-, size-, and compositiondependent properties of some colloidal semiconductor nanocrystals. Acc Chem Res. 2004;37:326-333.

12. Larguinho M, Baptista PV. Gold and silver nanooparticles for clinical diagnostics-from genomics to proteomics. J Proteomics. 2011. [Epub ahead of print.]

13. Conde J, Doria G, Baptista P. Noble metal nanoparticles applications in cancer. J Drug Deliv. 2011;2012:1-12.
14. Huang B, Zhang J, Hou J, Chen C. Free radical scavenging efficiency of nano-Se in vitro. Free Radic Biol Med. 2003;35:805-813.

15. Kajita M, Hikosaka K, Iitsuka M, Kanayama A, Toshima N, Miyamoto Y. Platinum nanoparticle is a useful scavenger of superoxide anion and hydrogen peroxide. Free Radic Res. 2007;41:615-626.

16. Kim J, Takahashi M, Shimizu T, et al. Effects of a potent antioxidant, platinum nanoparticle, on the lifespan of Caenorhabditis elegans. Mech Ageing Dev. 2008;129:322-331.

17. Varner K, El-Badaway A, Feldhake D, et al. State of the science literature review: everything nanosilver and more. EPA report, EPA/600/ R-10/89, 2010. Available from: http://www.epa.gov/nanoscience/files/ NanoPaper1.pdf. Accessed January 4, 2012.

18. Kalishwaralal K, Banumathi E, Ram Kumar Pandian S, et al. Silver nanoparticles inhibit VEGF induced cell proliferation and migration in bovine retinal endothelial cells. Colloids Surf B Biointerfaces. 2009;73:51-57.

19. Sun RW, Chen R, Chung NP, Ho CM, Lin CL, Che CM. Silver nanoparticles fabricated in herpes buffer exhibit cytoprotective activities toward HIV-1 infected cells. Chem Commun. 2005;40:5059-5061.

20. Tian J, Wong K, Ho CM, et al. Topical delivery of silver nanoparticles promotes wound healing. Chem Med Chem. 2007;2:129-136.

21. Park HS, Kim KH, Jang S, et al. Attenuation of allergic airway inflammation and hyperresponsiveness in a murine model of asthma by silver nanoparticles. Int J Nanomed. 2010;5:505-515.

22. Cho JY, Miller M, Baek KJ, et al. Inhibition of airway remodeling in IL-5-deficient mice. J Clin Invest. 2004;113:551-560.

23. Lee YC, Kwak YG, Song CH. Contribution of vascular endothelial growth factor to airway hyperresponsiveness and inflammation in a murine model of toluene diisocyanate-induced asthma. J Immunol. 2002;168:3595-3600.

24. Lee KS, Kim SR, Park HS, Jin GY, Lee YC. Cysteinyl leukotriene receptor antagonist regulates vascular permeability by reducing vascular endothelial growth factor expression. J Allergy Clin Immunol. 2004:114:1093-1099.

25. Zhong XS, Zheng JZ, Reed E, Jiang BH. SU5416 inhibited VEGF and HIF-1alpha expression through the PI3K/AKT/p70S6K1 signaling pathway. Biochem Biophys Res Commun. 2004;324:471-480.

26. Wilhelm SM, Carter C, Tang L, et al. BAY 43-9006 exhibits broad spectrum oral antitumor activity and targets the RAF/MEK/ERK pathway and receptor tyrosine kinases involved in tumor progression and angiogenesis. Cancer Res. 2004;64:7099-7109.

27. Wilhelm SM, Adnane L, Newell P, Villanueva A, Llovet JM, Lynch M. Preclinical overview of sorafenib, a multikinase inhibitor that targets both RAF and VEGF and PDGF receptor tyrosine kinase signaling. Mol Cancer Ther. 2008;7:3129-3140.

28. Ke Q, Costa M. Hypoxia-inducible factor-1. Mol Pharmacol. 2006; 70:1469-1480.

29. Semenza G. Regulation of oxygen homeostasis by hypoxia-inducible factor 1. Physiology. 2009;24:97-106.

30. Gariboldi MB, Ravizza R, Monti E. The IGFR1 inhibitor NVPQEW541 disrupts a pro-survival and pro-angiogenic IGF-STAT3HIF1 pathway in human glioblastoma cells. Biochem Pharmacol. 2010;80:455-462.

31. Hwang AB, Lee SJ. Regulation of life span by mitochondrial respiration: the HIF-1 and ROS connection. Aging. 2011;3:304-310.

32. Jing Y, Ma N, Fan T, et al. Tumor necrosis factor-alpha promotes tumor growth by inducing vascular endothelial growth factor. Cancer Invest. 2011;29:4485-4493

33. Jung Y, Isaacs JS, Lee S, Trepel J, Liu ZG, Neckers L. Hypoxia inducible factor induction by tumour necrosis factor in normoxic cells requires receptor interacting protein-dependent nuclear factor $\mathrm{kB}$ activation. Biochem J. 2003;370:1011-1017.

34. Lee KS, Kim SR, Park SJ, et al. Hydrogen peroxide induces vascular permeability via regulation of vascular endothelial growth factor. $\mathrm{Am}$ J Respir Cell Mol Biol. 2006;35:190-197.

35. Lee KS, Park SJ, Kim SR, et al. Phosphoinositide 3-kinase- $\delta$ inhibitor reduces vascular permeability in a murine model of asthma. $J$ Allergy Clin Immunol. 2006;118:403-409. 
36. Deudero JJ, Caramelo C, Castellanos MC, et al. Induction of hypoxiainducible factor 1 alpha gene expression by vascular endothelial growth factor. J Biol Chem. 2008;283:11435-11444.

37. Li YM, Zhou BP, Deng J, Pan Y, Hay N, Hung MC. A hypoxiaindependent hypoxia-inducible factor-1 activation pathway induced by phosphatidylinositol-3 kinase/Akt in HER2 overexpressing cells. Cancer Res. 2005;65:3257-3263.

38. Kim S, Shao MX, Nadel JA. Mucus production, secretion, and clearance. In: Mason RJ, Broaddus VC, Murray JF, Nadel JA, editors. Murray and Nadel's Textbook of Respiratory Medicine. 4th ed. Philadelphia, PA: Elsevier Saunders. 2005;1:330-354.

39. Jeong JH, Jeong YJ, Cho HJ, et al. Ascochlorin inhibits growth factorinduced HIF- $1 \alpha$ activation and tumor-angiogenesis through the suppression of EGFR/ERK/p70S6K signaling pathway in human cervical carcinoma cells. J Cell Biochem. 2011. [Epub ahead of print.]

40. Laughner E, Taghavi P, Chiles K, Mahon PC, Semenza GL. HER2 (Neu) signaling increases the rate of hypoxia-inducible factor 1alpha (HIF1alpha) synthesis: novel mechanism for HIF-1-mediated vascular endothelial growth factor expression. Mol Cell Biol. 2001;21:3995-4004.

41. Yu H, Li Q, Kolosov VP, et al. Regulation of cigarette smoke-mediated mucin expression by hypoxia-inducible factor- $1 \alpha$ via epidermal growth factor receptor-mediated signaling pathways. J Appl Toxicol. 2011. [Epub ahead of print.]

42. Burrows N, Babur M, Resch J, et al. GDC-0941 inhibits metastatic characteristics of thyroid carcinomas by targeting both the phosphoinositide-3 kinase (PI3K) and hypoxia-inducible factor-1 $\alpha$ (HIF-1 $\alpha$ ) pathways. J Clin Endocrinol Metab. 2011;96(12):E1934-E1943.

43. Takeyama K, Fahy JV, Nadel JA. Relationship of epidermal growth factor receptors to goblet cell production in human bronchi. Am J Respir Crit Care Med. 2001;163:511-516.

44. Amishima M, Munakata M, Nasuhara Y, et al. Expression of epidermal growth factor and epidermal growth factor receptor immunoreactivity in the asthmatic human airway. Am J Respir Crit Care Med. 1998; 157:1907-1912.

45. Polosa R, Puddicombe SM, Krishna MT, et al. Expression of C-ErbB receptors and ligands in the bronchial epithelium of asthmatic subjects. J Allergy Clin Immunol. 2002;109:75-81.

46. Mosca E, Barcella M, Alfieri R, et al. Systems biology of the metabolic network regulated by the Akt pathway. Biotechnol Adv. 2011. [Epub ahead of print.]

47. Somanath PR, Razorenova OV, Chen J, et al. Akt1 in endothelial cell and angiogenesis. Cell Cycle. 2006;5:512-518.

48. Jiang BH, Liu LZ. PI3K/PTEN signaling in angiogenesis and tumorigenesis. Adv Cancer Res. 2009;102:19-65.

49. Lee KS, Kim SR, Park SJ, et al. Mast cells can mediate vascular permeability through regulation of the PI3K-HIF-1alpha-VEGF axis. Am J Respir Crit Care Med. 2008;178:787-797.

50. Young HW, Williams OW, Chandra D, et al. Central role of Muc5ac expression in mucous metaplasia and its regulation by conserved $5^{\prime}$ elements. Am J Respir Cell Mol Biol. 2007;37:273-290.
51. Escande F, Porchet N, Bernigaud A, Petitprez D, Auert JP, Buisine MP. The mouse secreted gel-forming mucin gene cluster. Biochem Biophys Acta. 2004;1676:2405-2250.

52. Chen Y, Zhao YH, Kalaslavadi TB, et al. Genome-wide search and identification of a novel gel-forming mucin MUC19/Muc19 in glandular tissues. Am J Respir Cell Mol Biol. 2004;30:155-165.

53. Culp DJ, Latchney LR, Fallon MA, et al. The gene encoding mouse Muc19: CDNA, genomic organization and relationship to Smgc. Physiol Genomics. 2004;19:303-318.

54. Chen Y, Zhao YH, Di YP, We R. Characterization of human mucin $5 \mathrm{~b}$ gene expression in airway epithelium and the genomic clone of the amino-terminal and 5'-flanking region. Am J Respir Cell Mol Biol. 2001;25:542-553.

55. Evans CM, Koo JS. Airway mucus: the good, the bad, the sticky. Pharmacol Ther. 2009;121:332-348.

56. Groneberg DA, Eynott PR, Oates T, et al. Expression of MUC5AC and MUC5B mucins in normal and cystic fibrosis lung. Respir Med. 2002;96:81-86

57. Whittaker L, Niu N, Temann UA, et al. Interleukin-13 mediates a fundamental pathway for airway epithelial mucus induced by CD4 T Cells and interleukin-9. Am J Respir Cell Mol Biol. 2002;27:593-602.

58. Evans CM, Williams OW, Tuvim MJ, et al. Mucin is produced by clara cells in the proximal airways of antigen-challenged mice. Am J Respir Cell Mol Biol. 2004;31:382-394.

59. Busse PJ, Fahy JV. Airway mucus and the mucociliary system. In: Adkinson NF Jr, Bochner BS, Busse WW, Holgate ST, Lemanske RF Jr, Simons FE, editors. Middleton's Allergy Principles and Practice. 7th ed. Philadelphia, PA: Mosby Elsevier Inc. 2009;1:659-677.

60. Senapati S, Das S, Batra S. Mucin-interacting proteins: from function to therapeutics. Trends Biochem Sci. 2010;35:236-245.

61. Tyner JW, Kim EY, Ide K, et al. Blocking airway mucous cell metaplasia by inhibiting EGFR antiapoptosis and IL-13 transdifferentiation signals. J Clin Invest. 2006;116:309-321.

62. Burgel PR, Lazarus SC, Tam DC, et al. Human eosinophils induce mucin production in airway epithelial cells via epidermal growth factor receptor activation. J Immunol. 2001;167:5948-5954.

63. Shao MX, Nakanaga T, Nadel JA. Cigarette smoke induces MUC5AC mucin overproduction via tumor necrosis factor-alpha-convertingenzyme in human airway epithelial (NCI-H292) cells. Am J Physiol Lung Cell Mol Physiol. 2004;287:L420-L427.

64. Shim JJ, Dabbagh I, Ueki I, et al. IL-13 induces mucin production by stimulating epidermal growth factor receptors and by activating neutrophils. Am J Physiol Lung Cell Mol Physiol. 2001;280:L134-L140.

65. Takeyama K, Jung B, Shim JJ, et al. Activation of epidermal growth factor receptors is responsible for mucin synthesis induced by cigarette smoke. Am J Physiol Lung Cell Mol Physiol. 2001;280:L165-L172.

66. Agrawal A, Rengarajan S, Adler KB, et al. Inhibition of mucin secretion with MARCKS-related peptide improves airway obstructioin in a mouse model of asthma. J Appl Physiol. 2007;102:399-405. 


\section{Supplementary material}

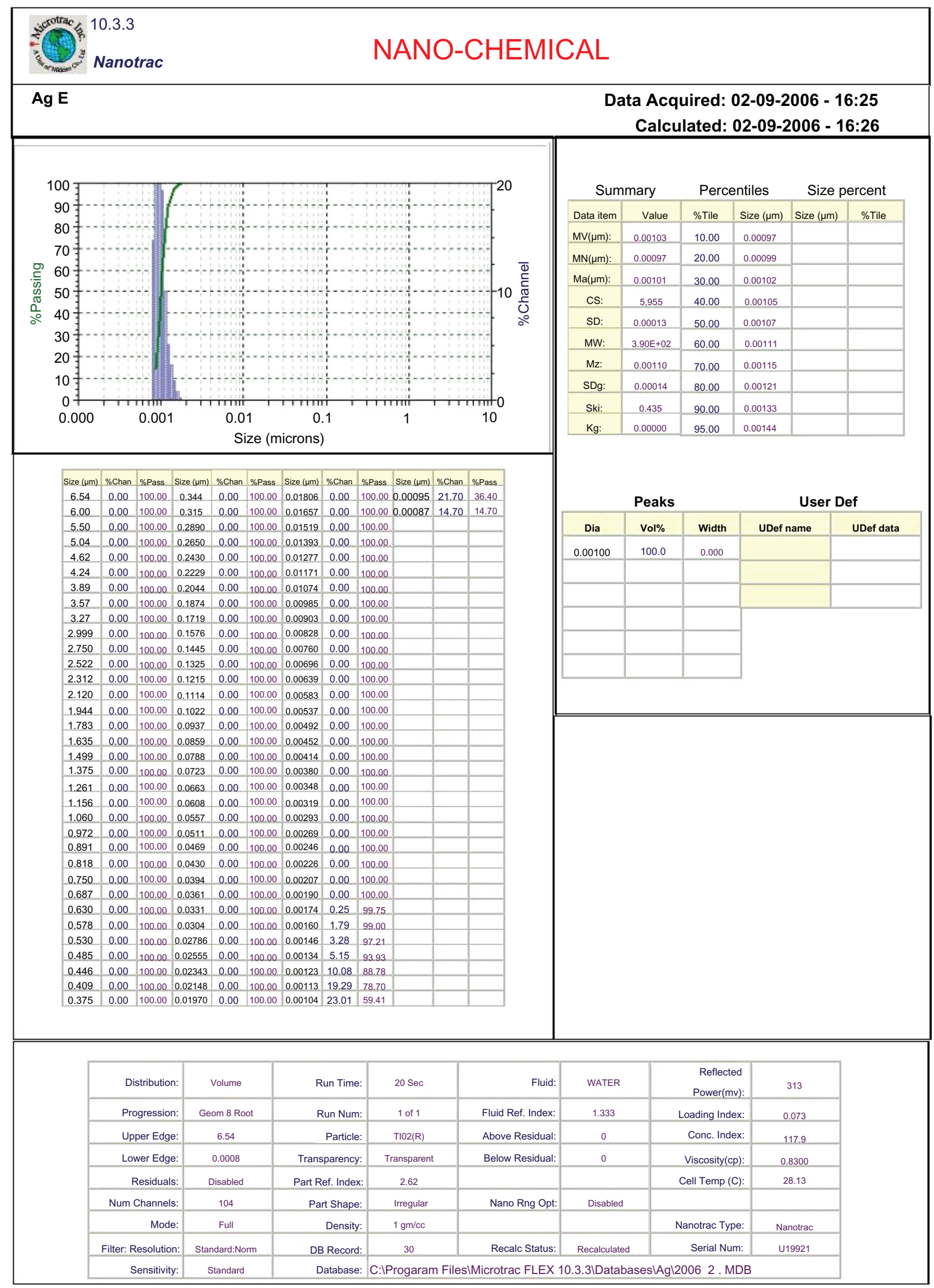


10.3.3

Nanotrac

\section{NANO-CHEMICAL}

$\mathrm{Ag} \mathrm{E}$

Data Acquired: 02-09-2006 - 16:25

Calculated: 02-09-2006 - 16:27

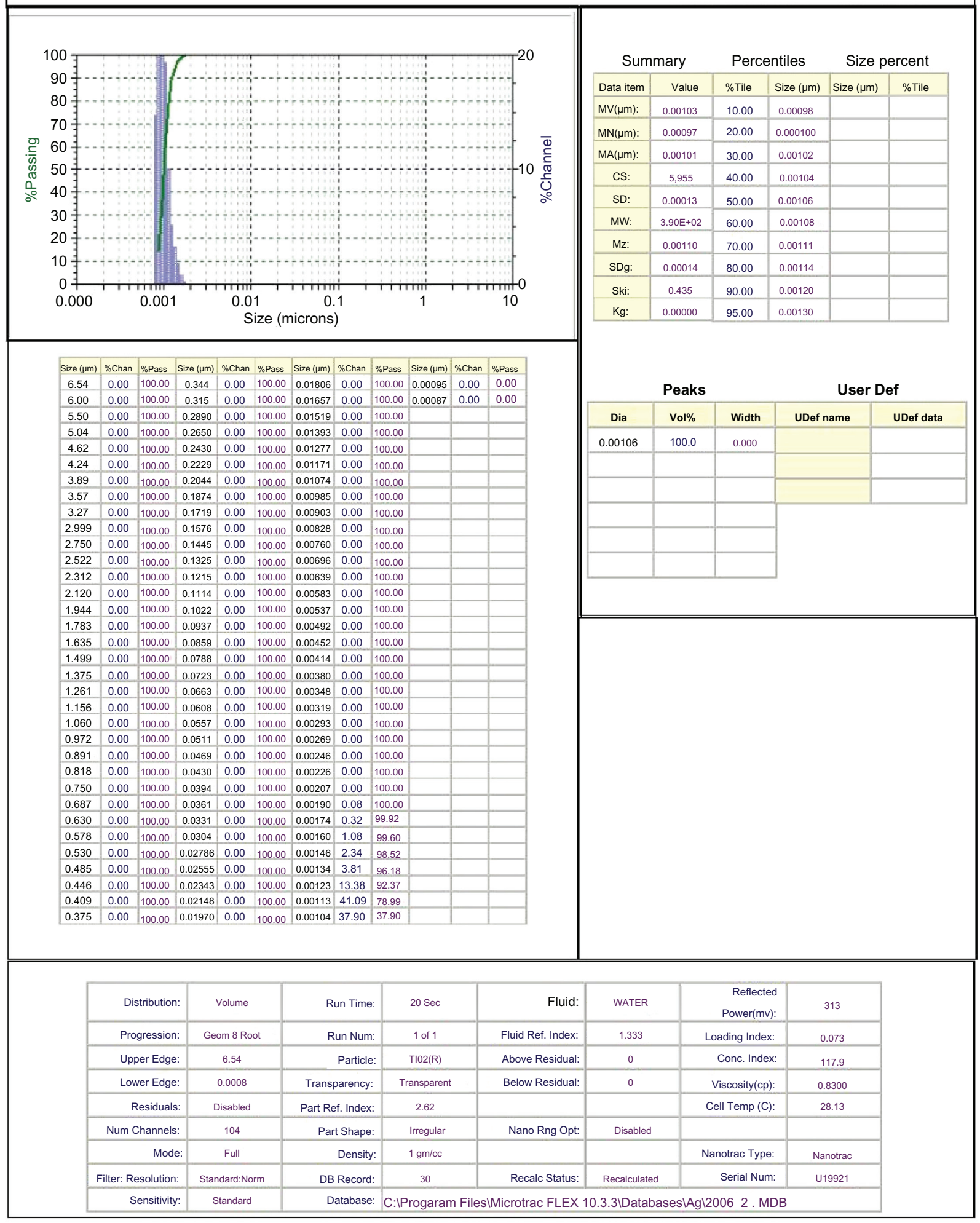


International Journal of Nanomedicine

Dovepress

\section{Publish your work in this journal}

The International Journal of Nanomedicine is an international, peerreviewed journal focusing on the application of nanotechnology in diagnostics, therapeutics, and drug delivery systems throughou the biomedical field. This journal is indexed on PubMed Central, MedLine, CAS, SciSearch ${ }^{\circledR}$, Current Contents ${ }^{\circledR} /$ Clinical Medicine,
Journal Citation Reports/Science Edition, EMBase, Scopus and the Elsevier Bibliographic databases. The manuscript management system is completely online and includes a very quick and fair peer-review system, which is all easy to use. Visit http://www.dovepress.com/ testimonials.php to read real quotes from published authors.

Submit your manuscript here: http://www.dovepress.com/international-journal-of-nanomedicine-journal 